OPEN ACCESS

Edited by:

Mara Bonelli,

University of Parma, Italy

Reviewed by:

Melissa García Caballero,

University of Malaga, Spain

Anca Maria Cimpean,

Victor Babes University of Medicine

and Pharmacy, Romania

*Correspondence:

Ming Chu

famous@bjmu.edu.cn

Specialty section:

This article was submitted to

Pharmacology of Anti-Cancer Drugs,

a section of the journal

Frontiers in Oncology

Received: 25 September 2021

Accepted: 13 December 2021

Published: 06 January 2022

Citation:

Wang $C$ and Chu M (2022)

Advances in Drugs Targeting Lymphangiogenesis for Preventing

Tumor Progression and Metastasis.

Front. Oncol. 11:783309.

doi: 10.3389/fonc.2021.783309

\section{Advances in Drugs Targeting Lymphangiogenesis for Preventing Tumor Progression and Metastasis}

\author{
Chuqi Wang ${ }^{1,2}$ and Ming $\mathrm{Chu}^{1 *}$ \\ 1 Department of Immunology, School of Basic Medical Sciences, Peking University, National Health Commission (NHC) Key \\ Laboratory of Medical Immunology (Peking University), Beijing, China, 2 I.M. Sechenov First Moscow State Medical University, \\ Moscow, Russia
}

Metastasis of cancer cells from the primary tumor to other organs and tissues in the body is the leading cause of death in patients with malignancies. One of the principal ways cancer cells travel is through lymphatic vessels, and tumor invasion into the regional lymph nodes is a hallmark of early metastasis; thus, the formation of especially peritumoral lymphatic vessels is essential for tumor transportation that gives rise to further progression. In the past few decades, tumor-induced lymphangiogenesis has been testified to its tight correlation with lymphatic metastasis and poor clinical outcomes in multiple types of human malignancies, which warrants novel potential therapeutic targets for cancer treatment. As the understanding of underlying molecular mechanisms has grown tremendously over the years, an inexorable march of anti-lymphangiogenic therapy also aroused terrific interest. As a result, a great number of drugs have entered clinical trials, and some of them exhibited predominant contributions in cancer management. Herein, this review provides an updated summary of the current advances in therapies preventing lymphatic metastasis and discusses the validity of different applications.

Keywords: lymphangiogenesis, VEGFR-2/-3, VEGF-C/-D, metastasis, tyrosine kinase inhibitor, angiogenesis, HGF, antibody

\section{INTRODUCTION}

Lymphangiogenesis is known as the formation of lymphatic vessels from pre-existing lymphatic vasculature. It participates in various physiological settings like homeostasis, immunity, embryonic development, and wound healing, while pathologically, this process is ordinarily implicated in organ graft rejection, lymphedema, and cancer metastasis. Additionally, other than the conventional views, many novel functions and roles of the lymphatic vasculature were uncovered more recently. Research has shown that an alteration of lymphangiogenesis can result in human pathologies such as obesity, aging, cardiovascular diseases including myocardial infarction and atherosclerosis, ocular diseases especially glaucoma, and inflammatory bowel diseases like Chron's disease. Some neurological disorders, including neurodegenerative diseases like Alzheimer's disease and Parkinson's disease, and multiple sclerosis, can also be regulated by meningeal lymphatics (1). The correlation with cancer metastasis, whereas not equally solid in every tissue, occurred commonly in melanoma, breast cancer, colorectal cancer, and squamous cell carcinoma of head and neck (2). However, unlike tumorinduced angiogenesis which has been well recognized since decades ago and the first drug to inhibit 
this process, Avastin, became available in the clinics from 2004 (3). The initial interest in lymphangiogenesis started with the detection of pro-lymphangiogenic factors VEGF-C in 1996 (4) and VEGF-D in 1997 (5), causing relatively delayed development of antilymphangiogenic therapy compared to that of anti-angiogenic therapy. Fortunately, over the past few years, our growing understanding of the signaling events regulating lymphangiogenesis has advanced on the heels of investigations utilizing podoplanin, LYVE-1, PROX-1, desmoplakin, and VEGFR-3 as the lymphatic endothelial cell(LEC)-specific markers (6).

Tumor cells and tumor-associated inflammatory cells express lymphangiogenic growth factors as well as cytokines that initiate signaling cascades to drive lymphatic vessel growth via different LEC surface receptors. Despite the participation of multiple receptors and the sophisticated process, it is commonly acknowledged that the main mechanism underlying lymphangiogenesis is through the VEGFR-3 signaling pathway (7), which enhances LEC survival, migration, and proliferation. After the interaction with high-affinity ligands VEGF-C and VEGF-D, VEGFR-3 is induced to form homodimers and VEGFR-2/-3 heterodimers, followed by phosphorylation and activation of the receptor (8). Cytoplasmic signaling mediators like Grb2 and SOS are then recruited to specific phosphorylated tyrosine sites to activate the subsequent Ras-Raf-MEK-ERK pathway. Concomitantly, other major downstream signaling, including PKC-dependent ERK, PI3K/Akt, and MKK4 mediated JNK1/2 pathways, are elicited via the corresponding phosphotyrosine residue sites (9). Multiple regulators such as membrane proteins $\beta 1$ integrin (10), EphrinB2 (11), and coreceptor neuropilin $2(\mathrm{Nrp} 2)(12)$, are proposed to facilitate receptor activation, internalization, or augment ligands' affinity, respectively.

In addition, adjacent LECs interact with each other to promote lymphangiogenesis, mainly through Ang/Tie2, DLL4/Notch1, and EFNB2/EPHB4 signaling (13). The Ang/Tie pathway was newly detected for its extra function of facilitating tumor growth in a cervical cancer model (14), which drew increased attention for its potential as a novel target in treatments. Angiopoietin-1 causes autophosphorylation of the Tie-2 receptor, leading to FAK/ERK and PI3K/Akt stimulation. While PI3K/Akt plays a critical role in the process, it is stimulated by another high-yield mechanism, the HGF/HGFR signaling. There was increased c-MET expression observed in both inflammatory and tumor-induced lymphatic vessels, and HGF-c-MET interaction could indirectly upregulate the VEGF/VEGFR expression via activating NF-kB molecule (15). Furthermore, current research highlighted that the fatty acids $\beta$ oxidation participated in the LEC PROX-1 interaction with histone acetyltransferase p300 to enhance lymphangiogenesis (16). Other than those noted above, VEGF-A/VEGFR-2, EGFR, FGF, and PDGF were reported to have notable effects in lymphatic vessel remodeling as well, helping to define diverse potential antilymphangiogenic targets.

Studies of lymphangiogenic pathway molecules have provided promising therapeutic targets and novel rationale for future cancer metastasis control (17) (Figure 1). So far, the main discovered molecules that serve as potential targets are VEGFC, VEGF-D, VEGFR-2, VEGFR-3, HGF, and HGFRs. In earlier studies of the angiogenic process, many of these molecules have also shown their promoting effects on angiogenesis; and fortunately, until 2018, there have been 26 drugs approved by FDA for the anti-angiogenic therapy, with various indications (18). In recent years, during the concurrent studies that were carried out to detect approaches targeting lymphangiogenesis, multiple anti-angiogenic drugs exhibited inhibitory effects on lymphangiogenesis as well, advancing the progression in this field. According to their targets and modes of action, drugs targeting lymphangiogenesis can be categorized into several groups: 1) Antibody-based therapies (19), including monoclonal antibodies and some neutralizing antibodies or peptides directly targeting the VEGF-C/VEGFR-3 axis, which are currently tested in preclinical/clinical studies; the HGF/HGFR and newly identified Ang/Tie also served as their targets. 2) Small molecule kinase inhibitors, functioning as a separate group of drugs that efficiently dampen the common receptor pathways (20), among which several agents have already been approved for their anti-angiogenic effects and anti-tumor properties in clinical use; there are two major groups of receptor targets for the tyrosine kinase inhibitors, which are VEGFRs and HGFRs. 3) Preclinical candidate agents targeting the lymphangiogenic pathways at different levels via various mechanisms, including downregulation of the VEGF/VEGFR expression, induction of the p21 dependent pathway to trigger cell cycle arrest, and suppression of the Akt, ERK and NF-kB signaling.

\section{DRUGS TARGETING TUMOR LYMPHANGIOGENESIS}

\section{Antibody Drugs}

Among the antibody drugs targeting the VEGF/VEGFR axis (Table 1), Bevacizumab was approved primarily as an antiangiogenic drug in various malignancies, and more clinical trials were taken to assess its precise anti-lymphangiogenic effects in combination therapy. A current study showed that, by inhibiting VEGF-A induced inflammatory (lymph) angiogenesis, Bevacizumab could benefit corneal pathologies and was studied as a novel strategy in corneal and ocular surface diseases (41). In 2011, a human IgG subclass $1 \mathrm{mAb}$ (monoclonal antibody) specific to VEGFR-3, IMC-3C5, entered the clinical trial and has recently completed the phase 1 study. It was shown to be well tolerated up to a dosage of $30 \mathrm{mg} / \mathrm{kg}$ weekly (qwk) in advanced solid tumors, though the following expanded evaluation of its activity on colorectal cancer (CRC) was minimal (22). Similarly, VGX-100 was another highly specific monoclonal antibody that explicitly binds to VEGF-C and dampens VEGFR-2 and VEGFR3 activation. It entered the phase 1 trial of late-stage cancers, among which the primary indications were glioblastoma and metastatic CRC (42). VGX-100 was well tolerated when it was used alone or combined with Bevacizumab, and $12 \%$ of the evaluated patients obtained a best response of durable stable disease for more than four months (23). Another preclinical stage study revealed a phage-derived single-chain fragment of anti-VEGF-C mAb (anti-VEGF-C scFv). By interacting with the epitope on VEGF-C, scFv showed distinct specificity and affinity. 


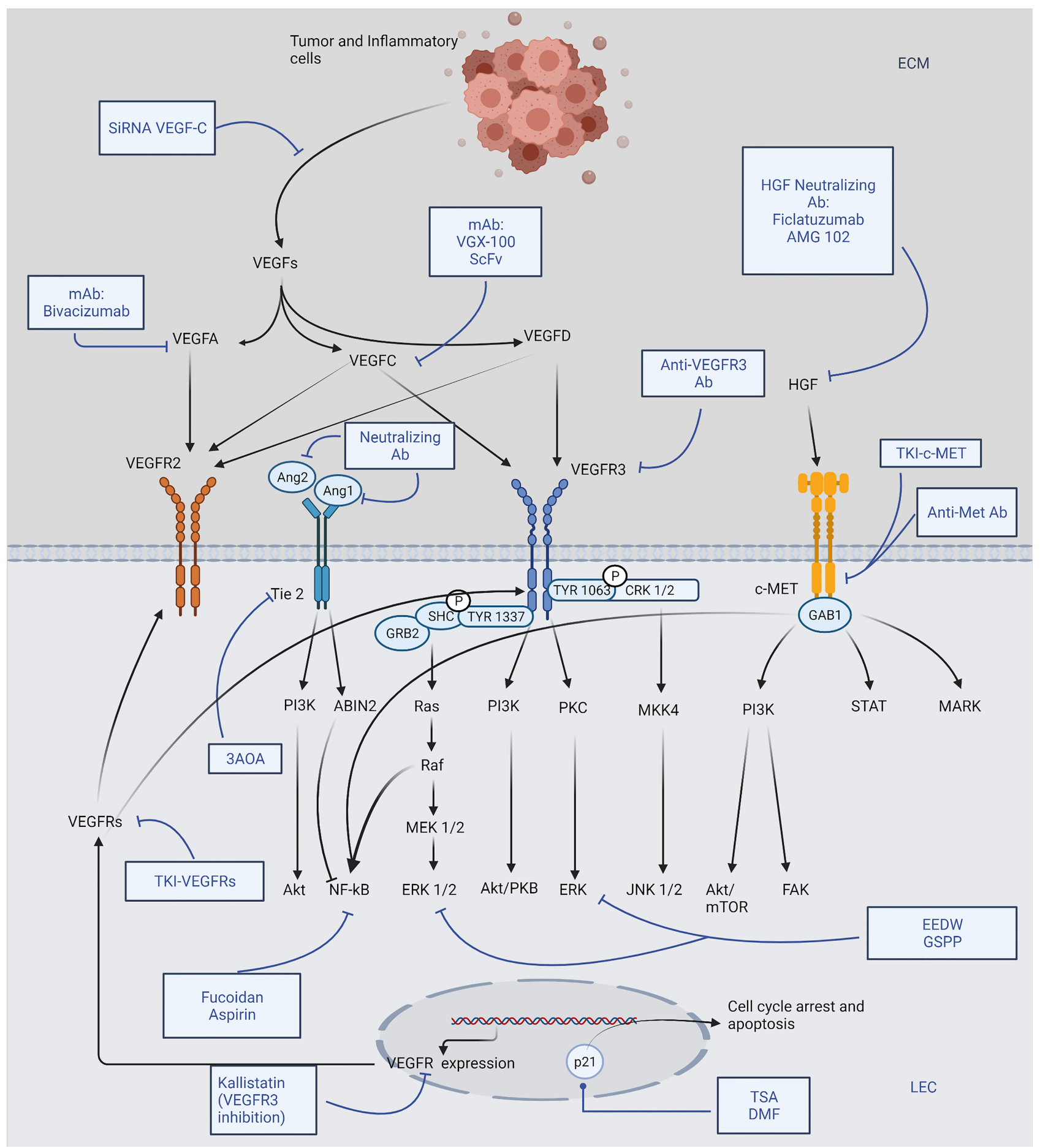

FIGURE 1 | Brief scheme representing major lymphangiogenic pathways and drugs targeting lymphangiogenesis. Tumor cells and tumor-associated inflammatory cells induce LEC (Iymphatic endothelial cell) proliferation, migration mainly through VEGF-C/-D expression, which activates subsequent VEGFR-2/-3 phosphorylation, leading to lymphangiogenesis. Various antibody drugs are shown to suppress the corresponding growth factors directly; membrane receptors, including VEGFRs, Tie2, and HGFRs, are also promising therapeutic targets. TKls against VEGFRs and HGFRs work alongside the mAb (monoclonal antibody) and neutralizing antibodies; 3AOA (3-O-Acetyloleanolic acid) is a novel agent dampening Tie2 receptor. In addition, many drugs exert an inhibitory effect on the essential downstream pathways of the receptors: EEDW (Hedyotis diffusa Willd) and GSPP (Gekko Sulfated Glycopeptide) inhibit ERK signaling while Fucoidan and Aspirin effectively suppress NF-kB; TSA (Trichostatin A) and DMF (Dimethyl fumarate) could induce cell cycle arrest via upregulating p21 dependent pathways; Kallistatin and SiRNA VEGF-C are examples of drugs inhibiting VEGF-C and VEGFR-3 expression, respectively. The figure was created with BioRender.com. 
TABLE 1 | Potential Ab drugs targeting lymphangiogenesis.

\begin{tabular}{|c|c|c|c|c|c|}
\hline Target & Agent name & Mode of action & Indications & Status & Reference \\
\hline \multirow[t]{8}{*}{$\begin{array}{l}\text { VEGF/ } \\
\text { VEGFR }\end{array}$} & Bevacizumab & Anti-VEGF-A mAb & $\begin{array}{l}\text { metastatic } \mathrm{CRC} \text {, non-squamous non-small cell lung cancer, recurrent } \\
\text { glioblastoma, hepatocellular carcinoma }(\mathrm{HCC})\end{array}$ & $\begin{array}{l}\text { FDA- } \\
\text { approved }\end{array}$ & $(21)$ \\
\hline & IMC-3C5 (LY3022856) & Anti-VEGFR-3 mAb & $\mathrm{CRC}$ & phase 1 & $(22)$ \\
\hline & VGX-100 & Anti-VEGF-C mAb & glioblastoma (GBM), metastatic colorectal cancers, prostate cancer & phase 1 & (23) \\
\hline & Diabody & $\begin{array}{l}\text { Anti-VEGFR-2NEGFR-3 } \\
\text { mAb }\end{array}$ & ovarian cancer, prostate cancer, CRC & phase 1 & (24) \\
\hline & Anti-VEGFR-3 peptide & Anti-VEGFR-3 peptide & skin cancer & preclinical & $(25)$ \\
\hline & sVEGFR-3-FC & $\begin{array}{l}\text { Soluble VEGFR-3 decoy } \\
\text { receptor }\end{array}$ & prostate cancer, melanoma & preclinical & $(26)$ \\
\hline & VEGFR-31-lg & $\begin{array}{l}\text { Receptor-lg fusion protein } \\
\text { (VEGF-ANEGF-C) }\end{array}$ & $\mathrm{HCC}$ & preclinical & $(27)$ \\
\hline & $\begin{array}{l}\text { single-chain fragment } \\
\text { (scFv) }\end{array}$ & Anti-VEGF-C mAb fragment & & preclinical & $(28)$ \\
\hline \multirow{5}{*}{$\begin{array}{l}\text { HGF/ } \\
\text { c-MET }\end{array}$} & Onartuzumab & Anti-MET Ab & non-small-cell lung cancer & phase 3 & (29) \\
\hline & ARGX-111 & Anti-MET Ab & mammary carcinoma & phase 1 & $(30,31)$ \\
\hline & $\begin{array}{l}\text { Telisotuzumab (ABT- } \\
700)\end{array}$ & Anti-MET mAb & non-small-cell lung cancer (NSCLC) & phase 1 & $(32)$ \\
\hline & Ficlatuzumab & HGF neutralizing $\mathrm{Ab}$ & head and neck squamous cell carcinoma; acute myeloid leukemia & phase 2 & (33) \\
\hline & $\begin{array}{l}\text { Rilotumumab (AMG } \\
\text { 102) }\end{array}$ & HGF neutralizing $A b$ & gastric cancer & phase 3 & (34) \\
\hline \multirow[t]{6}{*}{$\begin{array}{l}\text { Ang1/ } \\
\text { Ang2 }\end{array}$} & Trebananib (AMG 386) & $\begin{array}{l}\text { Ang1/Ang2 neutralizing } \\
\text { peptibody }\end{array}$ & recurrent ovarian cancer (phase 1/2 for various cancer types) & phase 3 & (35) \\
\hline & CVX-060 & Ang2 neutralizing CovX-body & metastatic renal cell carcinoma & phase 1 & $(36)$ \\
\hline & AMG 780 & Ang1/Ang2 neutralizing $\mathrm{Ab}$ & advanced solid tumors & phase 1 & (37) \\
\hline & MEDI 3617 & Ang2 neutralizing $A b$ & ovarian cancer & phase 1 & (38) \\
\hline & $\begin{array}{l}\text { Nesvacumab/ } \\
\text { Aflibercept (REGN 910) }\end{array}$ & Ang2 neutralizing $\mathrm{Ab}$ & adrenocortical carcinoma, HCC & phase 1 & $(39)$ \\
\hline & CVX-241 & $\begin{array}{l}\text { Ang2NEGF neutralizing } \\
\text { bispecific CovX-body }\end{array}$ & advanced solid tumors & phase 1 & $(40)$ \\
\hline
\end{tabular}

Significant advantages of such drugs can be shown in cancers depending on the direct VEGF-C pathway for growth, like Kaposi sarcoma and acute myeloid or lymphocytic leukemia. Researchers also speculated additional benefits of these inhibitors in VEGF-C induced bone and macular degeneration (28). An IgG-like fusion protein molecule, VEGFR-31-Ig, which could simultaneously bind the angiogenic VEGF-A and the lymphangiogenic VEGF$\mathrm{C}$, has been reported. It was remarkable for its outstanding stability and comparable effect with the complex activity of VEGF-Trap (25 mg/kg) and sVEGFR-3 (25 mg/kg), whereas excluding their conventional drawbacks like impractical clinical use and inadequate preclinical safety (27). Also, based on a current database analysis of the VEGF-C/VEGFR-3 triggered KRAS/MAPK-YAP1/Slug signaling in skin cancer progression, a unique anti-VEGFR-3 peptide was discovered able to abrogate the process (25).

Another axis targeted by antibody drugs was the HGF/HGFR signaling. A phase 3 study of Rilotumumab (AMG 102) with Epirubicin, Cisplatin and Capecitabine (CX) as first-line therapy in advanced MET-positive gastric or gastroesophageal junction adenocarcinoma was taken. However, the trial was terminated with a disappointing result as the Rilotumumab group presented a lower median overall survival (OS) and 12-month survival rate compared to the placebo arm, and it was associated with frequent fetal events such as neutropenia (29\%) and anemia (12\%) (34). Filcatuzumab was assessed in combination with Cetuximab for refractory head and neck squamous cell carcinoma due to minor benefits shown by Cetuximab alone. The combination had an acceptable safety profile and a promising anti-tumor activity by dual inactivation of HGF and EGFR pathways, indicating an active mitigation of cancer progression (33). Nonetheless, results from a phase 3 study of Onartuzumab with Erlotinib in nonsmall cell lung cancer (NSCLC) were in stark contrast to the previous phase consequence, partially due to the small size of the phase 2 study (29). Although it is dubious that the selection of patients group would affect, future investigations were expected to pick splice-site mutations harbored tumor samples (43). Taken together with the failure to meet the endpoint by many other MET-signaling inhibitors, researchers implied an unsatisfactory perspective of Ab therapy targeting this axis.

Fortunately, several agents inhibiting the interaction between Angiopoietin-1/-2 and the Tie2 receptor were demonstrated with promising efficacy. Trebananib, an angiopoietin neutralizing peptibody, prolonged the progression-free survival in a phase 3 trial of patients with recurrent epithelial ovarian cancer, proving the effectiveness of targeting this non-VEGF pathway (35). But some recent trials of Trebananib in combination with standard ovarian cancer chemotherapy didn't succeed in the overall survival improvement (44). Later designed AMG 780 had a relatively longer half-life duration ( 8 to 13 days) than that of Trebananib (3.1 to 6.3 days), and the phase 1 study of AMG 780 suggested a maximum dose of up to $30 \mathrm{mg} / \mathrm{kg}$ every 2 weeks in patients with advanced solid tumors (37). Selective anti-Ang2 mAb MEDI3617 was studied for its recommended monotherapy dosage and effects 
when combined with Bevacizumab and several other chemotherapies. Within the recommended single-agent dosage (1000 mg Q2W; $1500 \mathrm{mg}$ Q3W), there was no worsening of adverse effects like edema in combined treatments, yet the study of MEDI 3617 monotherapy in advanced ovarian cancers was discontinued due to the observation of peripheral edema (38). More recently, Nesvacumab showed preliminary anti-tumor activity in a phase 1 trial and the safety profile was acceptable at all dose levels tested (39). Combination therapy of Nesvacumab with Aflibercept was also well tolerated (45). Some additional investigations were taken in retinal diseases like macular degeneration though they failed to meet the phase 2 endpoint (46). Some chemically programmed antibodies behaving as potent endothelin receptor antagonists, like CVX-060 and CVX-241, were designed to target Ang2. However, CVX-241 was prematurely terminated because of the absence of ideal pharmacological effects through the $25 \mathrm{mg} / \mathrm{kg}$ cohort and shorter than expected half-life duration (40). CVX-060 plus Axitinib were tested in patients with previously treated metastatic renal cell cancer, and as a result of the higher than anticipated treatment-related thromboembolic events, enrollment to the next part was discontinued, but alternate doses and/or disease settings were considered (36). Although peripheral edema occurred as common toxicity that appeared in antiangiopoietin treatments, all the known cases were limited to grade 1 or 2, and no anti-VEGF therapy associated adverse effects were observed. Therefore, it might be noteworthy to combine antiangiopoietin drugs with conventional inhibitors of VEGF pathways to further augment the overall survival in some refractory cases.

\section{Small Molecule Tyrosine Kinase Inhibitors}

So far, FDA has approved several tyrosine kinase inhibitors (TKI) targeting VEGFRs for their significant improvement of progression-free survival in patients with renal cell carcinoma, thyroid cancer, hepatocellular carcinoma, and multiple other tumor types (Table 2). For example, in addition to the approved anti-angiogenic activity in malignancies, Pazopanib demonstrated favorable inhibitory effects on tumor growth, lymphatic metastasis, and tumor lymphangiogenesis in an orthotopic model of mice with colorectal cancer (56). Lenvatinib had versatile applications and predominantly suppressed lymph node metastasis in a breast cancer model, and for further studies of Lenvatinib-therapies, guiding biomarkers and sufficient selection of patients are needed (53). Triple angiokinase inhibitor, Nintedanib, adequately dampened lymphangiogenesis stimulated by VEGF-C, bFGF, and PDGF$\mathrm{BB}$ in a suture-induced corneal neovascularization assay. Both topical and systemic applications showed positive results, though the in vivo safety of topical use wasn't tested yet (52). Interestingly, other than the clinical application in renal cell carcinoma, Axitinib significantly inhibited LEC proliferation and lymphangiogenesis in a study of allergic asthma (68). An earlier establishment of Sunitinib in the breast cancer model presented marked reduction of tumor lymphatic and blood vessels density, as well as decreased axillary lymph nodes invasion, suggesting a prosperous blockade of LEC cellular function by dampening VEGFR-2/-3 activation from VEGF-C/-D (54). However, a controversy arose based on the observation of promoted lymphangiogenesis caused by the increase of VEGF-C transcription and mRNA stabilization in clear cell renal cell carcinomas (55). The paradoxical effects of Sunitinib treatment in different cancer models suggested a variation of LEC response in different tissues, implying a more appropriate patient sample will be needed for further confirmation of many other drugs also. It is noticeable that, as for future studies of these multi-kinase inhibitors, management of some common adverse effects, including drug-induced hypertension and dermatotoxicity like

TABLE 2 | potential anti-lymphangiogenic TKIs targeting VEGFRs.

\begin{tabular}{|c|c|c|c|c|c|}
\hline \multicolumn{2}{|l|}{ Target } & Agent name & \multirow[t]{2}{*}{ Indications } & \multirow{2}{*}{$\begin{array}{c}\text { Status } \\
\text { FDA-approved }\end{array}$} & \multirow{2}{*}{$\begin{array}{r}\text { Reference } \\
(47,48)\end{array}$} \\
\hline VEGFRs & (PDGFR, c-Kit, MET, FLT3, RET) & Cabozantinib & & & \\
\hline VEGFRs & (PDGFRs, FGFRs, BRAF, c-Kit, RET) & Regorafenib & CRC, HCC, gastrointestinal stromal tumor & FDA-approved & $(18,49)$ \\
\hline VEGFRs & (PDGFRs, c-kit, RET) & Sorafenib & $\begin{array}{l}\text { renal cell carcinoma, HCC, thyroid cancer } \\
\text { desmoid tumors }\end{array}$ & $\begin{array}{l}\text { FDA-approved } \\
\text { phase } 3\end{array}$ & $(50,51)$ \\
\hline VEGFRs & (PDGFRs, FGFR, PDGFR) & Nintedanib & $\begin{array}{l}\text { idiopathic pulmonary fibrosis, NSCLC } \\
\text { inflammatory corneal lymphangiogenesis }\end{array}$ & $\begin{array}{l}\text { FDA-approved } \\
\text { preclinical }\end{array}$ & $(52)$ \\
\hline \multicolumn{2}{|c|}{ VEGFR-2/-3 } & Lenvatinib (MK-7902/E7080) & $\begin{array}{l}\text { thyroid cancer } \\
\text { breast cancer }\end{array}$ & $\begin{array}{l}\text { FDA-approved } \\
\text { preclinical }\end{array}$ & $(53)$ \\
\hline VEGFRs & (PDGFRs, c-kit, Flt3, RET) & Sunitinib & $\begin{array}{l}\text { renal cell carcinoma } \\
\text { breast cancer }\end{array}$ & $\begin{array}{l}\text { FDA-approved } \\
\text { preclinical }\end{array}$ & $(54,55)$ \\
\hline VEGFRs & (PDGFRs, c-kit) & Pazopanib & $\begin{array}{l}\text { renal cell carcinoma, soft tissue sarcoma } \\
\text { CRC }\end{array}$ & $\begin{array}{l}\text { FDA-approved } \\
\text { preclinical }\end{array}$ & $(56)$ \\
\hline VEGFRs & (PDGFRs, c-kit) & Cediranib & relapsed ovarian caner & phase 3 & $(57)$ \\
\hline VEGFRs & (PDGFRs, FGFRs) & Brivanib & $\mathrm{HCC}$ & phase 3 & (58) \\
\hline VEGFRs & (PDGFRs) & SU-014813 & metastatic breast cancer & phase 2 & (59) \\
\hline VEGFR-3 & (EGFR-1/-2/-4, Src family) & JNJ-26483327 & advanced solid tumors & phase 1 & $(60)$ \\
\hline VEGFR-2 & $/-3$ & L-783277 derivative 17 & 3D-microfluidic tumor lymphangiogenesis assay & preclinical & (61) \\
\hline VEGFR-3 & & MAZ51 & melanoma & preclinical & (62) \\
\hline VEGFR-3 & & Toluquinol & corneal pathologies & preclinical & (63) \\
\hline VEGFR-2 & /-3 (ERK1/2, AKT) & AD0157 & breast cancer, human myeloid leukemia & preclinical & $(64,65)$ \\
\hline VEGFR-3 & (more selective than VEGFR-1/-2) & SAR 131675 & diabetic nephropathy & preclinical & $(66)$ \\
\hline VEGFR-3 & & Ki23057 & gastric carcinoma & preclinical & (67) \\
\hline
\end{tabular}


the hand-foot skin reaction, should be considered while estimating the clinical parameters.

Concurrently, there are extensive ongoing trials and preclinical studies of novel therapeutics. Investigations have been taken to test the synergistic effect of combining Vatalanib (750 mg BID) with the mTOR inhibitor, Everolimus $(10 \mathrm{mg}$ QD), and a $20 \%$ increase in the response rate was detected through this combination (compared to Everolimus therapy alone) in neuroendocrine tumors (69). Selective dual inhibitor Brivanib was studied in patients with hepatocellular carcinoma who were intolerant to Sorafenib or for whom Sorafenib failed. Still, the trial didn't meet the primary endpoint of overall survival, and similar negative results were taken by several other phase 3 trials of hepatocellular carcinoma (HCC) (58). Favorable results were shown in combination therapy of Cediranib and Olaparib (PARP inhibitor) with significantly extended effectiveness than Olaparib alone in patients having relapsed, platinum-sensitive ovarian cancer (57), which was consistent with previous studies. Moreover, preclinical studies of MAZ51 (a selective VEGFR-3 inhibitor) established a valid blockade of prostate tumor growth (70) and melanoma metastasis (62), as well as a $30 \%$ reduction in gastric cancer cell migration (71). Another highly selective strategy using SAR131675 has presented diminished lipotoxicity-induced lymphangiogenesis in a type 2 diabetic nephropathy model (66). AD0157 (a marine fungal metabolite), as a natural antiangiogenic compound, was shown to possess a pro-apoptotic property in human myeloid leukemia cells by inducing the caspase-dependent cascades (64). Concomitantly, other than the caspase-dependent apoptosis, it could also attenuate tumor-associated lymphangiogenesis and metastatic dissemination to both regional lymph nodes and distant organs by decreasing VEGFR-3/-2, ERK1/2, and Akt phosphorylation in human myeloid leukemia cells (65).

The other potent group of TKI is the MET kinase inhibitor (Table 3). In the recent two years, FDA granted approval to selective MET inhibitor Capmatinib and Tepotinib for adult patients with metastatic NSCLC whose tumors were MET exon 14 mutated. However, adverse effects like phototoxicity and interstitial lung diseases were reported (74). In the study of EMD 1214063 and EMD 1204831, both candidates triggered tumor regression in a dose-related fashion by inhibiting c-MET phosphorylation, regardless of HGF-dependent or HGFindependent activation. Comparatively, the former was more sustained. A single dose of EMD 1214063 at 10 or $30 \mathrm{mg} / \mathrm{kg}$ could achieve a complete and persistent target inhibition, making it better than many other MET inhibitors (81). PF-04217903 is one of the most selective c-MET inhibitors. It provided a robust TGI (tumor growth inhibition) in the MET-amplified GTL-16 model and a U87MG model exhibiting the HGF/c-MET autocrine loop (80). In clinical trials, multi-kinase inhibitor Crizotinib was approved for the treatment of ALK-positive NSCLC. It was relatively non-toxic though resistance may occur within one year (72). Several other drugs were discontinued in the study, like AMG 337, which was terminated early because of low response ( $13 \%$ of evaluable patients) observed during the phase 2 trial partially due to the larger sample and narrower range of tumor types (77).

\section{Candidate Agents}

A previous study utilizing the CI66 tumor model suggested that the siRNA-mediated VEGF-C gene silencing could efficiently suppress tumor lymphangiogenesis as well as recruitment of inflammatory cells in TME (tumor microenvironment) and calcium carbonate nanoparticle was believed to be a prosperous vector for it (Table 4). Furthermore, a higher level of dendritic cells and concanavalin A-induced proliferation in tumor-associated leukocytes was associated with the siVEGF-C application, indicating an additional positive modulation of the immune response (95). In vitro study of Fucoxanthin showed decreased lymph node metastases and significant reduction of in vivo LVD (lymphatic vessel density) in an MDA-MB-231 breast cancer model. Enhanced blocking of matrix metalloproteinases (MMP) secretion and increased TIMP-1 protein expression were also demonstrated in the experimental data of Fucoxanthin (84). Shikonin, according to the report, possessing a favorable inhibitory effect of NF-kB nuclear translocation and activation, causing the decrement of LEC cord formation (87). As an endogenous angiogenic inhibitor, Kallistatin was shown to be a potential dual-effect substance disrupting both VEGFR-2 \& VEGFR-3. Because of severe adverse effects appearing in VEGFR TKIs treatment, combination therapy of Kallistatin with the kinase inhibitors could thus be considered a new strategy (85). Meanwhile, a highly metastatic human lung

TABLE 3 | potential anti-lymphangiogenic TKIs targeting HGFRs(c-MET).

\begin{tabular}{|c|c|c|c|c|}
\hline Target & Agent name & Indications & Status & Reference \\
\hline C-MET (ALK, ROS1) & Crizotinib & sarcoma and sarcomatoid malignancies harboring ALK fusions & FDA-approved & $(72,73)$ \\
\hline C-MET & Capmatinib & NSCLC & FDA-approved & $(74)$ \\
\hline C-MET & Tepotinib (MSC 2156119/EMD 1214063 & NSCLC & FDA-approved & $(74)$ \\
\hline C-MET & Tivantinib & NSCLC, HCC & phase 3 & $(75)$ \\
\hline C-MET & Savolitinib & NSCLC & phase 2 & (76) \\
\hline C-MET & AMG 337 & gastric/gastric esophageal junction/esophageal tumors & phase 2 & $(77)$ \\
\hline c-MET/Ron & AMG 208 & prostate cancer & phase 2 & (78) \\
\hline c-MET (VEGFR-2) & Foretinib & glioblastoma, gastric cancer & phase 2 & (79) \\
\hline C-MET & PF-04217903 & $\mathrm{CRC}$ & phase 1 & (80) \\
\hline c-MET & EMD 1204831 & solid tumors & phase 1 & $(81)$ \\
\hline c-MET/Ron & MK-8033 & advanced cancer & phase 1 & (82) \\
\hline
\end{tabular}


TABLE 4 | Preclinical anti-lymphangiogenic candidate agents.

\begin{tabular}{|c|c|c|c|c|}
\hline Agent name & Mode of action & Conventional usages & Novel indications & Reference \\
\hline Celecoxib & COX-2 inhibition & $\begin{array}{l}\text { osteoarthritis, rheumatoid } \\
\text { arthritis }\end{array}$ & $\begin{array}{l}\text { highly metastatic lung } \\
\text { adenocarcinoma }\end{array}$ & (83) \\
\hline Fucoxanthin & VEGF-CNEGFR-3 depression; NF-kB degradation & obesity, diabetes mellitus & breast cancer & (84) \\
\hline Kallistatin & inhibition of VEGFR-3 expression & vascular and organ injury & gastric cancer & (85) \\
\hline Oxyresveratrol & downregulation of VEGF-CNEGFR-3 expression & $\begin{array}{l}\text { hyperpigmentation } \\
\text { disorders }\end{array}$ & $\mathrm{HCC}$ & (86) \\
\hline Shikonin & inhibition of NF-kB/HIF-1 $\alpha$ pathway & flat wart, psoriasis & & $(87)$ \\
\hline $\begin{array}{l}\text { Qingjie Fuzheng Granules } \\
\text { (QFG) }\end{array}$ & $\begin{array}{l}\text { suppression of VEGF-CNEGFR-3 dependent PI3K/AKt } \\
\text { pathway }\end{array}$ & $\begin{array}{l}\text { cancer (as adjuvant } \\
\text { therapy) }\end{array}$ & CRC & (88) \\
\hline Fucoidan & inhibition of NF-kB/PI3K/Akt pathway & dietary supplements & & (89) \\
\hline Aspirin & inhibition of NF-kB/VCAM-1 pathway & $\begin{array}{l}\text { angina pectoris, ankylosing } \\
\text { spondylitis }\end{array}$ & & (90) \\
\hline $\begin{array}{l}\text { EEHDW (Hedyotis diffusa } \\
\text { Willd }\end{array}$ & inhibition of ERK, PI3K/AKt, STAT3 pathway & $\begin{array}{l}\text { cancer (as adjuvant } \\
\text { therapy) }\end{array}$ & $\mathrm{CRC}$ & $(91)$ \\
\hline $\begin{array}{l}\text { GSPP (Gekko Sulfated } \\
\text { Glycopeptide) }\end{array}$ & inhibition of bFGF induced ERK1/2 signaling & $\begin{array}{l}\text { cancer (as adjuvant } \\
\text { therapy) }\end{array}$ & & $(92)$ \\
\hline Curcumin & inhibition of HMGB1/NEGF-C, VEGFR-2/-3 signaling & $\begin{array}{l}\text { dietary supplement, food } \\
\text { additive }\end{array}$ & gastric cancer & (93) \\
\hline Dimethyl fumarate & induction of G1 cell cycle arrest & multiple sclerosis, psoriasis & & $(94)$ \\
\hline SiRNA VEGF-C & downregulation of VEGF-C expression & & breast cancer & (95) \\
\hline 3АOA (3-O- & inhibition of Ang-1/Tie-2; suppression of VEGF-A induced & & colon cancer, oral squamous & $(96,97)$ \\
\hline Acetyloleanolic acid) & VEGFR-1/-2 phosphorylation & & cell carcinoma & \\
\hline Phomaketide A & inhibition of VEGFR-3, PKC $\delta$, and eNOS signaling cascades & & & $(98)$ \\
\hline $\begin{array}{l}\text { LHbisD4 (heparin } \\
\text { conjugate) }\end{array}$ & blockade of VEGF-C induced signaling pathway & & breast cancer & (99) \\
\hline Trichostatin A & induction of G0/G1-arrest & & & $(100)$ \\
\hline
\end{tabular}

adenocarcinoma cell line Anip973 revealed an increase in both VEGF-C \& COX-2 immunoreactivity, indicating a possible correlation in between. Therefore COX-2 (largely from PGE2stimulated EP4 receptors) and EP4 may serve as novel targets for treatment in light of its potential regulatory activity on VEGF-C expression (83). Many other agents like Fucoidan (89), Aspirin (90), Hedyotis diffusa Willd (EEHDW) (91), and Curcumin (93) were able to block the important downstream signalings of VEGFR-3 in various cancer models. Interestingly, an earlier study explicated an advantageous inhibitory effect of VEGF-A induced lymphangiogenesis and sentinel lymph node metastasis in oral cancer by 3AOA. Besides the VEGF-A inhibition, 3-OAcetyloleanolic acid (3AOA) also interfered with an alternative lymphangiogenic pathway mediated by Ang-1/Tie-2 in the CT26 colon carcinoma model. $5 \mu \mathrm{M}$ 3AOA could significantly dampen $87 \%$ of human umbilical vein endothelial cells (HUVEC) proliferation, migration, and tube formation stimulated by Ang-1 (96, 97). Similarly, 6,8-Diprenylgenistein (6,8-DG), an isoflavonoid isolated from Cudrania tricuspidata has been reported with its inhibitory effect on VEGF-A induced lymphangiogenesis as well. In the oral cancer model, 6,8-DG inhibited VEGF-A expression and blocked the VEGFR-2 interaction with VEGF-A, decreasing cervical lymph nodes metastasis of the oral squamous cell carcinoma (101). Newly examined histone deacetylase inhibitors Trichostatin A (TSA) (100) and Dimethyl fumarate (DMF) (94) both caused G1 cell cycle arrest in a p21-dependent manner. DMF had a pronounced anti-tumorigenic effect for melanoma and a cell type-specific cell cycle arrest. No apoptotic influence was observed in DMFtreated human DLEC (dermal lymphatic endothelial cells), while TSA, on the other hand, downregulated the antiapoptotic proteins cIAP-1/2, causing cell death.

\section{DISCUSSION}

Tumor-induced lymphangiogenesis and therapeutics providing virtual management of lymphatic metastasis will continue their upward trend in advances based on the successive achievements. Targeting the VEGF-C/VEGFR-3 at different levels remained the major approach due to the increasing confirmation for its essential role in the lymphangiogenic mechanism and a growing understanding of the axis. Newly discovered targets still need further investigation for their accurate regulatory effects in various tumors, whereas some of them, like angiopoietin and genetic transcription factors, were already considered plausible in addition to the VEGF/VEGFR pathway to reduce the common adverse effects associated with VEGF therapies. Although there haven't been any FDA-approved antilymphangiogenic drugs yet, accumulated favorable results, especially from small molecular VEGFR inhibitors, were presented in clinical studies. Most of the examined TKIs were selected from existing anti-angiogenic applications and exhibited promising therapeutic effects. However, single-agent treatment, for example, with monoclonal antibodies alone, received minor therapeutic responses; thus, current anti-lymphangiogenic investigations focus more or less on combining antilymphangiogenic methods with other standard anti-tumor drugs due to the extended involvement of different mechanisms in cancer progression. It is noteworthy that, apart 
from the medications from anti-angiogenic therapy, many preclinical studies (Table 4) have discovered some conventional drugs and molecules with a more predominant effect on lymphangiogenesis; simultaneously, applications with a selective VEGF-C and VEGFR-3 depression were designed. In order to develop more drugs with specific anti-lymphangiogenic effects and find out the best strategy in each case to delineate the differences between anti-angiogenic and anti-lymphangiogenic therapy, several traditional Chinese herbs with conventional anti-tumor effects also enrolled in recent studies. Interestingly, they exhibited effective anti-lymphangiogenic activity via different mechanisms, shedding a light on a new group of potential therapeutics in this field.

Since angiogenesis, lymphangiogenesis, and neoplasia share many similar mechanisms and pathways, it's still necessary to continue to uncover some basic problems, such as what factors keep the blood vasculature apart from the lymphatic vessels after embryonic differentiation and the functional differences of each factor in blood endothelial cells and lymphatic endothelial cells. Also, some recent research pointed out that the LEC genetic pattern strongly influenced the lymphovascular response to the factors in different tissues, causing both functional and structural heterogeneity of tumor lymphangiogenesis. Hence, revealing specific molecular biomarkers in each particular cancer and tracing tumor LEC genetic lineage for their precise roles and mechanisms might be the upcoming challenges in future studies. Moreover, according to the paradoxical effects of lymphatic

\section{REFERENCES}

1. Oliver G, Kipnis J, Randolph GJ, Harvey NL. The Lymphatic Vasculature in the 21(St) Century: Novel Functional Roles in Homeostasis and Disease. Cell (2020) 182(2):270-96. doi: 10.1016/j.cell.2020.06.039

2. Dieterich LC, Detmar M. Tumor Lymphangiogenesis and New Drug Development. Adv Drug Deliv Rev (2016) 99(Pt B):148-60. doi: 10.1016/ j.addr.2015.12.011

3. Cohen MH, Gootenberg J, Keegan P, Pazdur R. FDA Drug Approval Summary: Bevacizumab (Avastin) Plus Carboplatin and Paclitaxel as First-Line Treatment of Advanced/Metastatic Recurrent Nonsquamous non-Small Cell Lung Cancer. Oncologist (2007) 12(6):713-8. doi: 10.1634/ theoncologist.12-6-713

4. Joukov V, Pajusola K, Kaipainen A, Chilov D, Lahtinen I, Kukk E, et al. A Novel Vascular Endothelial Growth Factor, VEGF-C, is a Ligand for the Flt4 (VEGFR-3) and KDR (VEGFR-2) Receptor Tyrosine Kinases. EMBO J (1996) 15(2):290-98. doi: 10.1002/j.1460-2075.1996.tb00359.x

5. Yamada Y, Nezu J, Shimane M, Hirata Y. Molecular Cloning of a Novel Vascular Endothelial Growth Factor, VEGF-D. Genomics (1997) 42(3):4838. doi: 10.1006/geno.1997.4774

6. Jha SK, Rauniyar K, Jeltsch M. Key Molecules in Lymphatic Development, Function, and Identification. Ann Anat = Anatomischer Anzeiger Off Organ Anatomische Gesellschaft (2018) 219:25-34. doi: 10.1016/j.aanat. 2018.05.003

7. Secker GA, Harvey NL. Regulation of VEGFR Signalling in Lymphatic Vascular Development and Disease: An Update. Int J Mol Sci (2021) 22 (14):3. doi: 10.3390/ijms22147760

8. Leppänen VM, Tvorogov D, Kisko K, Prota AE, Jeltsch M, Anisimov A, et al. Structural and Mechanistic Insights Into VEGF Receptor 3 Ligand Binding and Activation. Proc Natl Acad Sci USA (2013) 110(32):12960-5. doi: $10.1073 /$ pnas.1301415110

9. Salameh A, Galvagni F, Bardelli M, Bussolino F, Oliviero S. Direct Recruitment of CRK and GRB2 to VEGFR-3 Induces Proliferation, Migration, and Survival of Endothelial Cells Through the Activation of vessels in immune-cell trafficking, an accurate balance between the protumor and anti-tumor immune response is needed in order to improve the benefits of anti-lymphangiogenic therapies.

\section{AUTHOR CONTRIBUTIONS}

Literature review and writing-original draft preparation: CW. Writing-review and editing: MC. Supervision and funding acquisition: MC. All authors have read and agreed to the published version of the manuscript.

\section{FUNDING}

This work was supported by National Natural Science Foundation of China (81603119) and Natural Science Foundation of Beijing Municipality (7174316).

\section{ACKNOWLEDGMENTS}

This work was sponsored by the interdisciplinary medicine Seed Fund of Peking University BMU2021MX021; supported by the Fundamental Research Funds for the Central Universities. The figure in this manuscript was created with BioRender.com.

ERK, AKT, and JNK Pathways. Blood (2005) 106(10):3423-31. doi: 10.1182/ blood-2005-04-1388

10. Planas-Paz L, Strilić B, Goedecke A, Breier G, Fässler R, Lammert E. Mechanoinduction of Lymph Vessel Expansion. EMBO J (2012) 31 (4):788-804. doi: 10.1038/emboj.2011.456

11. Mäkinen T, Adams RH, Bailey J, Lu Q, Ziemiecki A, Alitalo K, et al. PDZ Interaction Site in Ephrinb2 is Required for the Remodeling of Lymphatic Vasculature. Genes Dev (2005) 19(3):397-410. doi: 10.1101/gad.330105

12. Xu Y, Yuan L, Mak J, Pardanaud L, Caunt M, Kasman I, et al. Neuropilin-2 Mediates VEGF-C-Induced Lymphatic Sprouting Together With VEGFR3. J Cell Biol (2010) 188(1):115-30. doi: 10.1083/jcb.200903137

13. Zheng W, Aspelund A, Alitalo K. Lymphangiogenic Factors, Mechanisms, and Applications. J Clin Invest (2014) 124(3):878-87. doi: 10.1172/JCI71603

14. Yang P, Chen N, Yang D, Crane J, Huang B, Dong R, et al. Cervical Cancer Cell-Derived Angiopoietins Promote Tumor Progression. Tumour Biol J Int Soc Oncodevelopmental Biol Med (2017) 39(7):1010428317711658. doi: 10.1177/1010428317711658

15. Kajiya K, Hirakawa S, Ma B, Drinnenberg I, Detmar M. Hepatocyte Growth Factor Promotes Lymphatic Vessel Formation and Function. EMBO J (2005) 24(16):2885-95. doi: 10.1038/sj.emboj.7600763

16. Wong BW, Wang X, Zecchin A, Thienpont B, Cornelissen I, Kalucka J, et al. The Role of Fatty Acid $\beta$-Oxidation in Lymphangiogenesis. Nature (2017) 542(7639):49-54. doi: 10.1038/nature21028

17. $\mathrm{Xu} \mathrm{W,} \mathrm{Harris} \mathrm{NR,} \mathrm{Caron} \mathrm{KM.} \mathrm{Lymphatic} \mathrm{Vasculature:} \mathrm{An} \mathrm{Emerging}$ Therapeutic Target and Drug Delivery Route. Annu Rev Med (2021) 72:167-82. doi: 10.1146/annurev-med-051419-114417

18. Yamakawa M, Doh SJ, Santosa SM, Montana M, Qin EC, Kong H, et al. Potential Lymphangiogenesis Therapies: Learning From Current Antiangiogenesis Therapies-A Review. Med Res Rev (2018) 38(6):1769-98. doi: $10.1002 /$ med.21496

19. Bzowska M, Mężyk-Kopeć R, Próchnicki T, Kulesza M, Klaus T, Bereta J. Antibody-Based Antiangiogenic and Antilymphangiogenic Therapies to Prevent Tumor Growth and Progression. Acta Biochim Polonica (2013) 60 (3):263-75. doi: 10.18388/abp.2013_1982 
20. Kannaiyan R, Mahadevan D. A Comprehensive Review of Protein Kinase Inhibitors for Cancer Therapy. Expert Rev Anticancer Ther (2018) 18 (12):1249-70. doi: 10.1080/14737140.2018.1527688

21. Bock F, Onderka J, Dietrich T, Bachmann B, Kruse FE, Paschke M, et al. Bevacizumab as a Potent Inhibitor of Inflammatory Corneal Angiogenesis and Lymphangiogenesis. Invest Ophthalmol Visual Sci (2007) 48(6):254552. doi: $10.1167 /$ iovs.06-0570

22. Saif MW, Knost JA, Chiorean EG, Kambhampati SR, Yu D, Pytowski B, et al. Phase 1 Study of the Anti-Vascular Endothelial Growth Factor Receptor 3 Monoclonal Antibody LY3022856/IMC-3C5 in Patients With Advanced and Refractory Solid Tumors and Advanced Colorectal Cancer. Cancer Chemother Pharmacol (2016) 78(4):815-24. doi: 10.1007/s00280-0163134-3

23. Falchook GS, Goldman JW, Desai J, Leitch I, Hong DS, Subbiah V, et al. A First-in-Human Phase I Study of VGX-100, a Selective Anti-VEGF-C Antibody, Alone and in Combination With Bevacizumab in Patients With Advanced Solid Tumors. J Clin Oncol (2014) 32(15_suppl):2524-. doi: 10.1200/jco.2014.32.15_suppl.2524

24. Jimenez X, Lu D, Brennan L, Persaud K, Liu M, Miao H, et al. A Recombinant, Fully Human, Bispecific Antibody Neutralizes the Biological Activities Mediated by Both Vascular Endothelial Growth Factor Receptors 2 and 3. Mol Cancer Ther (2005) 4(3):427-34. doi: 10.1158/1535-7163.Mct04-0261

25. Yeh YW, Cheng CC, Yang ST, Tseng CF, Chang TY, Tsai SY, et al. Targeting the VEGF-C/VEGFR3 Axis Suppresses Slug-Mediated Cancer Metastasis and Stemness via Inhibition of KRAS/YAP1 Signaling. Oncotarget (2017) 8 (3):5603-18. doi: 10.18632/oncotarget.13629

26. Lin J, Lalani AS, Harding TC, Gonzalez M, Wu WW, Luan B, et al. Inhibition of Lymphogenous Metastasis Using Adeno-Associated VirusMediated Gene Transfer of a Soluble VEGFR-3 Decoy Receptor. Cancer Res (2005) 65(15):6901-9. doi: 10.1158/0008-5472.Can-05-0408

27. Zhang D, Li B, Shi J, Zhao L, Zhang X, Wang C, et al. Suppression of Tumor Growth and Metastasis by Simultaneously Blocking Vascular Endothelial Growth Factor (VEGF)-A and VEGF-C With a Receptor-Immunoglobulin Fusion Protein. Cancer Res (2010) 70(6):2495-503. doi: 10.1158/00085472.Can-09-3488

28. Rinderknecht M, Villa A, Ballmer-Hofer K, Neri D, Detmar M. PhageDerived Fully Human Monoclonal Antibody Fragments to Human Vascular Endothelial Growth Factor-C Block its Interaction With VEGF Receptor-2 and 3. PloS One (2010) 5(8):e11941. doi: 10.1371/journal.pone.0011941

29. Spigel DR, Edelman MJ, O'Byrne K, Paz-Ares L, Mocci S, Phan S, et al. Results From the Phase III Randomized Trial of Onartuzumab Plus Erlotinib Versus Erlotinib in Previously Treated Stage IIIB or IV Non-Small-Cell Lung Cancer: METLung. J Clin Oncol Off J Am Soc Clin Oncol (2017) 35(4):41220. doi: $10.1200 /$ jco.2016.69.2160

30. Hultberg A, Morello V, Huyghe L, De Jonge N, Blanchetot C, Hanssens V, et al. Depleting MET-Expressing Tumor Cells by ADCC Provides a Therapeutic Advantage Over Inhibiting HGF/MET Signaling. Cancer Res (2015) 75(16):3373-83. doi: 10.1158/0008-5472.Can-15-0356

31. Aftimos P, Rolfo C, Rottey S, Barthélémy P, Borg C, Park K, et al. The NHance $\left({ }^{\circledR}\right)$ Mutation-Equipped Anti-MET Antibody ARGX-111 Displays Increased Tissue Penetration and Anti-Tumor Activity in Advanced Cancer Patients. Biomedicines (2021) 9(6):14. doi: 10.3390/biomedicines 9060665

32. Strickler JH, Weekes CD, Nemunaitis J, Ramanathan RK, Heist RS, Morgensztern D, et al. First-In-Human Phase I, Dose-Escalation and -Expansion Study of Telisotuzumab Vedotin, an Antibody-Drug Conjugate Targeting C-Met, in Patients With Advanced Solid Tumors. J Clin Oncol Off J Am Soc Clin Oncol (2018) 36(33):3298-306. doi: 10.1200/ jco.2018.78.7697

33. Kumar D, Kandl C, Hamilton CD, Shnayder Y, Tsue TT, Kakarala K, et al. Mitigation of Tumor-Associated Fibroblast-Facilitated Head and Neck Cancer Progression With Anti-Hepatocyte Growth Factor Antibody Ficlatuzumab. JAMA Otolaryngol Head Neck Surg (2015) 141(12):1133-9. doi: 10.1001/jamaoto.2015.2381

34. Catenacci DVT, Tebbutt NC, Davidenko I, Murad AM, Al-Batran SE, Ilson DH, et al. Rilotumumab Plus Epirubicin, Cisplatin, and Capecitabine as First-Line Therapy in Advanced MET-Positive Gastric or GastroOesophageal Junction Cancer (RILOMET-1): A Randomised, Double-
Blind, Placebo-Controlled, Phase 3 Trial. Lancet Oncol (2017) 18 (11):1467-82. doi: 10.1016/s1470-2045(17)30566-1

35. Monk BJ, Poveda A, Vergote I, Raspagliesi F, Fujiwara K, Bae DS, et al. AntiAngiopoietin Therapy With Trebananib for Recurrent Ovarian Cancer (TRINOVA-1): A Randomised, Multicentre, Double-Blind, PlaceboControlled Phase 3 Trial. Lancet Oncol (2014) 15(8):799-808. doi: 10.1016/s1470-2045(14)70244-x

36. Gollerkeri A, Gordon MS, Burke JM, Hauke R, Tomasek J, Richards DA, et al. Phase Ib Safety Trial of CVX-060, an Intravenous Humanized Monoclonal CovX Body Inhibiting Angiopoietin 2 (Ang-2), With Axitinib in Patients With Previously Treated Metastatic Renal Cell Cancer (RCC). J Clin Oncol (2013) 31(15_suppl):2533-. doi: 10.1200/jco.2013. 31.15_suppl.2533

37. Dowlati A, Vlahovic G, Natale RB, Rasmussen E, Singh I, Hwang YC, et al. First-In-Human Study of AMG 780, an Angiopoietin-1 and -2 Inhibitor, in Patients With Advanced Solid Tumors. Clin Cancer Res an Off J Am Assoc Cancer Res (2016) 22(18):4574-84. doi: 10.1158/1078-0432.Ccr-15-2145

38. Hyman DM, Rizvi N, Natale R, Armstrong DK, Birrer M, Recht L, et al. Phase I Study of MEDI3617, a Selective Angiopoietin-2 Inhibitor Alone and Combined With Carboplatin/Paclitaxel, Paclitaxel, or Bevacizumab for Advanced Solid Tumors. Clin Cancer Res an Off J Am Assoc Cancer Res (2018) 24(12):2749-57. doi: 10.1158/1078-0432.Ccr-17-1775

39. Papadopoulos KP, Kelley RK, Tolcher AW, Razak AR, Van Loon K, Patnaik A, et al. A Phase I First-In-Human Study of Nesvacumab (REGN910), a Fully Human Anti-Angiopoietin-2 (Ang2) Monoclonal Antibody, in Patients With Advanced Solid Tumors. Clin Cancer Res an Off J Am Assoc Cancer Res (2016) 22(6):1348-55. doi: 10.1158/1078-0432.Ccr-15-1221

40. Mendelson DS, Rosen LS, Gordon MS, Goldman JW, Olszanski AJ, Dai H, et al. First-In-Human Dose-Escalation Safety and PK Trial of a Novel Humanized Monoclonal CovX Body Dual Inhibitor of Angiopoietin 2 and Vascular Endothelial Growth Factor. J Clin Oncol (2011) 29 (15_suppl):3055-. doi: 10.1200/jco.2011.29.15_suppl.3055

41. Bock F, Maruyama K, Regenfuss B, Hos D, Steven P, Heindl LM, et al. Novel Anti(Lymph)Angiogenic Treatment Strategies for Corneal and Ocular Surface Diseases. Prog Retin Eye Res (2013) 34:89-124. doi: 10.1016/ j.preteyeres.2013.01.001

42. Tampellini M, Sonetto C, Scagliotti GV. Novel Anti-Angiogenic Therapeutic Strategies in Colorectal Cancer. Expert Opin Invest Drugs (2016) 25(5):50720. doi: 10.1517/13543784.2016.1161754

43. Awad MM, Oxnard GR, Jackman DM, Savukoski DO, Hall D, Shivdasani P, et al. MET Exon 14 Mutations in Non-Small-Cell Lung Cancer Are Associated With Advanced Age and Stage-Dependent MET Genomic Amplification and C-Met Overexpression. J Clin Oncol Off J Am Soc Clin Oncol (2016) 34(7):721-30. doi: 10.1200/jco.2015.63.4600

44. Vergote I, Scambia G, O'Malley DM, Van Calster B, Park SY, Del Campo JM, et al. Trebananib or Placebo Plus Carboplatin and Paclitaxel as First-Line Treatment for Advanced Ovarian Cancer (TRINOVA-3/ENGOT-Ov2/ GOG-3001): A Randomised, Double-Blind, Phase 3 Trial. Lancet Oncol (2019) 20(6):862-76. doi: 10.1016/s1470-2045(19)30178-0

45. Papadopoulos KP, Graham DM, Tolcher AW, Razak ARA, Patnaik A, Bedard PL, et al. A Phase 1b Study of Combined Angiogenesis Blockade With Nesvacumab, a Selective Monoclonal Antibody (MAb) to Angiopoietin-2 (Ang2) and Ziv-Aflibercept in Patients With Advanced Solid Malignancies. J Clin Oncol (2014) 32(15_suppl):2522-. doi: 10.1200/ jco.2014.32.15_suppl.2522

46. Al-Khersan H, Hussain RM, Ciulla TA, Dugel PU. Innovative Therapies for Neovascular Age-Related Macular Degeneration. Expert Opin Pharmacother (2019) 20(15):1879-91. doi: 10.1080/14656566.2019.1636031

47. Escudier B, Powles T, Motzer RJ, Olencki T, Arén Frontera O, Oudard S, et al. Cabozantinib, a New Standard of Care for Patients With Advanced Renal Cell Carcinoma and Bone Metastases? Subgroup Analysis of the METEOR Trial. J Clin Oncol Off J Am Soc Clin Oncol (2018) 36(8):765-72. doi: 10.1200/jco.2017.74.7352

48. Roskoski RJr. Vascular Endothelial Growth Factor (VEGF) and VEGF Receptor Inhibitors in the Treatment of Renal Cell Carcinomas. Pharmacol Res (2017) 120:116-32. doi: 10.1016/j.phrs.2017.03.010

49. Takigawa H, Kitadai Y, Shinagawa K, Yuge R, Higashi Y, Tanaka S, et al. Multikinase Inhibitor Regorafenib Inhibits the Growth and Metastasis of 
Colon Cancer With Abundant Stroma. Cancer Sci (2016) 107(5):601-8. doi: $10.1111 /$ cas. 12907

50. Gounder MM, Mahoney MR, Van Tine BA, Ravi V, Attia S, Deshpande HA, et al. Sorafenib for Advanced and Refractory Desmoid Tumors. N Engl J Med (2018) 379(25):2417-28. doi: 10.1056/NEJMoa 1805052

51. Bruix J, Cheng AL, Meinhardt G, Nakajima K, De Sanctis Y, Llovet J. Prognostic Factors and Predictors of Sorafenib Benefit in Patients With Hepatocellular Carcinoma: Analysis of Two Phase III Studies. J Hepatol (2017) 67(5):999-1008. doi: 10.1016/j.jhep.2017.06.026

52. Lin T, Gong L. Inhibition of Lymphangiogenesis In Vitro and In Vivo by the Multikinase Inhibitor Nintedanib. Drug Design Dev Ther (2017) 11:1147-58. doi: $10.2147 /$ dddt.S130297

53. Matsui J, Funahashi Y, Uenaka T, Watanabe T, Tsuruoka A, Asada M. Multi-Kinase Inhibitor E7080 Suppresses Lymph Node and Lung Metastases of Human Mammary Breast Tumor MDA-MB-231 via Inhibition of Vascular Endothelial Growth Factor-Receptor (VEGF-R) 2 and VEGF-R3 Kinase. Clin Cancer Res an Off J Am Assoc Cancer Res (2008) 14(17):545965. doi: 10.1158/1078-0432.Ccr-07-5270

54. Kodera Y, Katanasaka Y, Kitamura Y, Tsuda H, Nishio K, Tamura T, et al. Sunitinib Inhibits Lymphatic Endothelial Cell Functions and Lymph Node Metastasis in a Breast Cancer Model Through Inhibition of Vascular Endothelial Growth Factor Receptor 3. Breast Cancer Res BCR (2011) 13 (3):R66. doi: $10.1186 / \mathrm{bcr} 2903$

55. Dufies M, Giuliano S, Ambrosetti D, Claren A, Ndiaye PD, Mastri M, et al. Sunitinib Stimulates Expression of VEGFC by Tumor Cells and Promotes Lymphangiogenesis in Clear Cell Renal Cell Carcinomas. Cancer Res (2017) 77(5):1212-26. doi: 10.1158/0008-5472.Can-16-3088

56. Zhu G, Zhao M, Han Q, Tan Y, Sun YU, Bouvet M, et al. Pazopanib Inhibits Tumor Growth, Lymph-Node Metastasis and Lymphangiogenesis of an Orthotopic Mouse of Colorectal Cancer. Cancer Genomics Proteomics (2020) 17(2):131-9. doi: 10.21873/cgp.20173

57. Liu JF, Barry WT, Birrer M, Lee JM, Buckanovich RJ, Fleming GF, et al. Overall Survival and Updated Progression-Free Survival Outcomes in a Randomized Phase II Study of Combination Cediranib and Olaparib Versus Olaparib in Relapsed Platinum-Sensitive Ovarian Cancer. Ann Oncol Off J Eur Soc Med Oncol (2019) 30(4):551-7. doi: 10.1093/annonc/mdz018

58. Johnson PJ, Qin S, Park JW, Poon RT, Raoul JL, Philip PA, et al. Brivanib Versus Sorafenib as First-Line Therapy in Patients With Unresectable, Advanced Hepatocellular Carcinoma: Results From the Randomized Phase III BRISK-FL Study. J Clin Oncol Off J Am Soc Clin Oncol (2013) 31 (28):3517-24. doi: 10.1200/jco.2012.48.4410

59. de Jonge MJ, Dumez H, Kitzen JJ, Beuselinck B, Verweij J, Courtney R, et al. Phase I Safety and Pharmacokinetic Study of SU-014813 in Combination With Docetaxel in Patients With Advanced Solid Tumours. Eur J Cancer (Oxford Engl 1990) (2011) 47(9):1328-35. doi: 10.1016/j.ejca.2011.02.012

60. Konings IR, de Jonge MJ, Burger H, van der Gaast A, van Beijsterveldt LE, Winkler H, et al. Phase I and Pharmacological Study of the Broad-Spectrum Tyrosine Kinase Inhibitor JNJ-26483327 in Patients With Advanced Solid Tumours. Br J Cancer (2010) 103(7):987-92. doi: 10.1038/sj.bjc. 6605867

61. Han Y, Sengupta S, Lee BJ, Cho H, Kim J, Choi HG, et al. Identification of a Unique Resorcylic Acid Lactone Derivative That Targets Both Lymphangiogenesis and Angiogenesis. J Med Chem (2019) 62(20):914160. doi: $10.1021 /$ acs.jmedchem. $9 \mathrm{~b} 01025$

62. Lee JY, Hong SH, Shin M, Heo HR, Jang IH. Blockade of FLT4 Suppresses Metastasis of Melanoma Cells by Impaired Lymphatic Vessels. Biochem Biophys Res Commun (2016) 478(2):733-8. doi: 10.1016/j.bbrc.2016.08.017

63. García-Caballero M, Blacher S, Paupert J, Quesada AR, Medina MA, Noël A. Novel Application Assigned to Toluquinol: Inhibition of Lymphangiogenesis by Interfering With VEGF-C/VEGFR-3 Signalling Pathway. Br J Pharmacol (2016) 173(12):1966-87. doi: 10.1111/bph.13488

64. García-Caballero M, Martínez-Poveda B, Medina MA, Quesada AR. The Natural Antiangiogenic Compound AD0157 Induces Caspase-Dependent Apoptosis in Human Myeloid Leukemia Cells. Front Pharmacol (2017) 8:802. doi: $10.3389 /$ fphar.2017.00802

65. García-Caballero M, Paupert J, Blacher S, Van de Velde M, Quesada AR, Medina MA, et al. Targeting VEGFR-3/-2 Signaling Pathways With AD0157: A Potential Strategy Against Tumor-Associated Lymphangiogenesis and
Lymphatic Metastases. J Hematol Oncol (2017) 10(1):122. doi: 10.1186/ s13045-017-0484-1

66. Hwang SD, Song JH, Kim Y, Lim JH, Kim MY, Kim EN, et al. Inhibition of Lymphatic Proliferation by the Selective VEGFR-3 Inhibitor SAR131675 Ameliorates Diabetic Nephropathy in Db/Db Mice. Cell Death Dis (2019) 10 (3):219. doi: 10.1038/s41419-019-1436-1

67. Yashiro M, Shinto O, Nakamura K, Tendo M, Matsuoka T, Matsuzaki T, et al. Effects of VEGFR-3 Phosphorylation Inhibitor on Lymph Node Metastasis in an Orthotopic Diffuse-Type Gastric Carcinoma Model. $\mathrm{Br} J$ Cancer (2009) 101(7):1100-6. doi: 10.1038/sj.bjc.6605296

68. Moldobaeva A, Jenkins J, Zhong Q, Wagner EM. Lymphangiogenesis in Rat Asthma Model. Angiogenesis (2017) 20(1):73-84. doi: 10.1007/s10456-0169529-2

69. Zhu M, Molina JR, Dy GK, Croghan GA, Qi Y, Glockner J, et al. A Phase I Study of the VEGFR Kinase Inhibitor Vatalanib in Combination With the mTOR Inhibitor, Everolimus, in Patients With Advanced Solid Tumors. Invest New Drugs (2020) 38(6):1755-62. doi: 10.1007/s10637-020-00936-z

70. Yamamura A, Nayeem MJ, Muramatsu H, Nakamura K, Sato M. MAZ51 Blocks the Tumor Growth of Prostate Cancer by Inhibiting Vascular Endothelial Growth Factor Receptor 3. Front Pharmacol (2021) 12:667474. doi: 10.3389/fphar.2021.667474

71. Lim J, Ryu JH, Kim EJ, Ham S, Kang D. Inhibition of Vascular Endothelial Growth Factor Receptor 3 Reduces Migration of Gastric Cancer Cells. Cancer Invest (2015) 33(8):398-404. doi: 10.3109/07357907.2015.1047509

72. Sahu A, Prabhash K, Noronha V, Joshi A, Desai S. Crizotinib: A Comprehensive Review. South Asian J Cancer (2013) 2(2):91-7. doi: 10.4103/2278-330x.110506

73. Wu J, Hu Y, Abdihamid O, Huang G, Xiao S, Li B. Crizotinib in Sarcomatous Malignancies Harboring ALK Fusion With a Definitive Partner(s): Response and Efficacy. Front Oncol (2021) 11:684865. doi: 10.3389/fonc.2021.684865

74. Mathieu LN, Larkins E, Akinboro O, Roy P, Amatya AK, Fiero MH, et al. FDA Approval Summary: Capmatinib and Tepotinib for the Treatment of Metastatic NSCLC Harboring MET Exon 14 Skipping Mutations or Alterations. Clin Cancer Res an Off J Am Assoc Cancer Res (2021). doi: 10.1158/1078-0432.Ccr-21-1566

75. Kim BJ, Kim YJ, Sohn SH, Kim B, Sul HJ, Kim HS, et al. Tivantinib Inhibits the VEGF Signaling Pathway and Induces Apoptosis in Gastric Cancer Cells With C-MET or VEGFA Amplification. Invest N Drugs (2020) 38(6):163340. doi: 10.1007/s10637-020-00940-3

76. Gan HK, Millward M, Hua Y, Qi C, Sai Y, Su W, et al. First-In-Human Phase I Study of the Selective MET Inhibitor, Savolitinib, in Patients With Advanced Solid Tumors: Safety, Pharmacokinetics, and Antitumor Activity. Clin Cancer Res an Off J Am Assoc Cancer Res (2019) 25 (16):4924-32. doi: 10.1158/1078-0432.Ccr-18-1189

77. Hong DS, LoRusso P, Hamid O, Janku F, Kittaneh M, Catenacci DVT, et al. Phase I Study of AMG 337, a Highly Selective Small-Molecule MET Inhibitor, in Patients With Advanced Solid Tumors. Clin Cancer Res an Off J Am Assoc Cancer Res (2019) 25(8):2403-13. doi: 10.1158/1078-0432.Ccr-18-1341

78. Hong DS, Rosen P, Lockhart AC, Fu S, Janku F, Kurzrock R, et al. A First-inHuman Study of AMG 208, an Oral MET Inhibitor, in Adult Patients With Advanced Solid Tumors. Oncotarget (2015) 6(21):18693-706. doi: 10.18632/ oncotarget. 4472

79. Sohn SH, Kim B, Sul HJ, Choi BY, Kim HS, Zang DY. Foretinib Inhibits Cancer Stemness and Gastric Cancer Cell Proliferation by Decreasing CD44 and C-MET Signaling. OncoTargets Ther (2020) 13:1027-35. doi: 10.2147/ ott.S226951

80. Zou HY, Li Q, Lee JH, Arango ME, Burgess K, Qiu M, et al. Sensitivity of Selected Human Tumor Models to PF-04217903, a Novel Selective C-Met Kinase Inhibitor. Mol Cancer Ther (2012) 11(4):1036-47. doi: 10.1158/15357163.Mct-11-0839

81. Bladt F, Faden B, Friese-Hamim M, Knuehl C, Wilm C, Fittschen C, et al. EMD 1214063 and EMD 1204831 Constitute a New Class of Potent and Highly Selective C-Met Inhibitors. Clin Cancer Res an Off J Am Assoc Cancer Res (2013) 19(11):2941-51. doi: 10.1158/1078-0432.Ccr-12-3247

82. Keedy VL, Lenz HJ, Saltz L, Whisenant JG, Berlin JD, Camacho LH. First-InHuman Phase I Dose Escalation Study of MK-8033 in Patients With Advanced Solid Tumors. Invest N Drugs (2018) 36(5):860-8. doi: 10.1007/ s10637-018-0567-z 
83. Xin X, Majumder M, Girish GV, Mohindra V, Maruyama T, Lala PK. Targeting COX-2 and EP4 to Control Tumor Growth, Angiogenesis, Lymphangiogenesis and Metastasis to the Lungs and Lymph Nodes in a Breast Cancer Model. Lab Invest; J Tech Methods Pathol (2012) 92(8):111528. doi: 10.1038/labinvest.2012.90

84. Wang J, Ma Y, Yang J, Jin L, Gao Z, Xue L, et al. Fucoxanthin Inhibits Tumour-Related Lymphangiogenesis and Growth of Breast Cancer. J Cell Mol Med (2019) 23(3):2219-29. doi: 10.1111/jcmm.14151

85. Ma C, Yin H, Zhong J, Zhang Y, Luo C, Che D, et al. Kallistatin Exerts AntiLymphangiogenic Effects by Inhibiting Lymphatic Endothelial Cell Proliferation, Migration and Tube Formation. Int J Oncol (2017) 50 (6):2000-10. doi: 10.3892/ijo.2017.3972

86. Liu Y, Ren W, Bai Y, Wan L, Sun X, Liu Y, et al. Oxyresveratrol Prevents Murine H22 Hepatocellular Carcinoma Growth and Lymph Node Metastasis via Inhibiting Tumor Angiogenesis and Lymphangiogenesis. J Natural Medicines (2018) 72(2):481-92. doi: 10.1007/s11418-018-1173-2

87. Prangsaengtong O, Jantaree P, Lirdprapamongkol K, Svasti J, Koizumi K. Shikonin Suppresses Lymphangiogenesis via NF- $\mathrm{b} / \mathrm{HIF}-1 \alpha$ Axis Inhibition. Biol Pharm Bull (2018) 41(11):1659-66. doi: 10.1248/bpb.b1800329

88. Huang B, Lu Y, Gui M, Guan J, Lin M, Zhao J, et al. Qingjie Fuzheng Granule Suppresses Lymphangiogenesis in Colorectal Cancer via the VEGF-C/ VEGFR-3 Dependent PI3K/AKT Pathway. Biomed Pharmacother = Biomed Pharmacotherapie (2021) 137:111331. doi: 10.1016/ j.biopha.2021.111331

89. Yang Y, Gao Z, Ma Y, Teng H, Liu Z, Wei H, et al. Fucoidan Inhibits Lymphangiogenesis by Downregulating the Expression of VEGFR3 and PROX1 in Human Lymphatic Endothelial Cells. Oncotarget (2016) 7(25):38025-35. doi: 10.18632/oncotarget.9443

90. Prangsaengtong O, Jantaree P, Lirdprapamongkol K, Ngiwsara L, Svasti J, Koizumi K. Aspirin Suppresses Components of Lymphangiogenesis and Lymphatic Vessel Remodeling by Inhibiting the NF-Kb/VCAM-1 Pathway in Human Lymphatic Endothelial Cells. Vasc Med (London England) (2018) 23(3):201-11. doi: 10.1177/1358863x18760718

91. Li H, Lai Z, Yang H, Peng J, Chen Y, Lin J. Hedyotis Diffusa Willd. Inhibits VEGF -C-mediated Lymphangiogenesis in Colorectal Cancer. via Multiple Signaling Pathways Oncol Rep (2019) 42(3):1225-36. doi: 10.3892/or.2019.7223

92. Ding XL, Man YN, Hao J, Zhu CH, Liu C, Yang X, et al. The Antitumor Effect of Gekko Sulfated Glycopeptide by Inhibiting bFGF-Induced Lymphangiogenesis. BioMed Res Int (2016) 2016:7396392. doi: 10.1155/ 2016/7396392

93. Da W, Zhang J, Zhang R, Zhu J. Curcumin Inhibits the Lymphangiogenesis of Gastric Cancer Cells by Inhibiton of HMGB1/VEGF-D Signaling. Int J Immunopathol Pharmacol (2019) 33:2058738419861600. doi: 10.1177/ 2058738419861600

94. Valesky EM, Hrgovic I, Doll M, Wang XF, Pinter A, Kleemann J, et al. Dimethylfumarate Effectively Inhibits Lymphangiogenesis via P21
Induction and G1 Cell Cycle Arrest. Exp Dermatol (2016) 25(3):200-5. doi: $10.1111 /$ exd.12907

95. Chen Z, Varney ML, Backora MW, Cowan K, Solheim JC, Talmadge JE, et al. Down-Regulation of Vascular Endothelial Cell Growth Factor-C Expression Using Small Interfering RNA Vectors in Mammary Tumors Inhibits Tumor Lymphangiogenesis and Spontaneous Metastasis and Enhances Survival. Cancer Res (2005) 65(19):9004-11. doi: 10.1158/0008-5472.Can-05-0885

96. Hwang-Bo J, Park JH, Chung IS. 3-O-Acetyloleanolic Acid Inhibits Angiopoietin-1-Induced Angiogenesis and Lymphangiogenesis via Suppression of Angiopoietin-1/Tie-2 Signaling. Phytotherapy Res PTR (2020) 34(2):359-67. doi: 10.1002/ptr.6526

97. Hwang-Bo J, Bae MG, Park JH, Chung IS. 3-O-Acetyloleanolic Acid Inhibits VEGF-A-Induced Lymphangiogenesis and Lymph Node Metastasis in an Oral Cancer Sentinel Lymph Node Animal Model. BMC Cancer (2018) 18 (1):714. doi: 10.1186/s12885-018-4630-0

98. Tai HC, Lee TH, Tang CH, Chen LP, Chen WC, Lee MS, et al. Phomaketide A Inhibits Lymphangiogenesis in Human Lymphatic Endothelial Cells. Marine Drugs (2019) 17(4):8-10. doi: 10.3390/md17040215

99. Choi JU, Chung SW, Al-Hilal TA, Alam F, Park J, Mahmud F, et al. A Heparin Conjugate, LHbisD4, Inhibits Lymphangiogenesis and Attenuates Lymph Node Metastasis by Blocking VEGF-C Signaling Pathway. Biomaterials (2017) 139:56-66. doi: 10.1016/j.biomaterials.2017.05.026

100. Hrgovic I, Doll M, Kleemann J, Wang XF, Zoeller N, Pinter A, et al. The Histone Deacetylase Inhibitor Trichostatin a Decreases Lymphangiogenesis by Inducing Apoptosis and Cell Cycle Arrest via P21-Dependent Pathways. BMC Cancer (2016) 16(1):763. doi: 10.1186/s12885-016-2807-y

101. Bae MG, Hwang-Bo J, Lee DY, Lee YH, Chung IS. Effects of 6,8Diprenylgenistein on VEGF-A-Induced Lymphangiogenesis and Lymph Node Metastasis in an Oral Cancer Sentinel Lymph Node Animal Model. Int J Mol Sci (2021) 22(2):9-10. doi: 10.3390/ijms22020770

Conflict of Interest: The authors declare that the research was conducted in the absence of any commercial or financial relationships that could be construed as a potential conflict of interest.

Publisher's Note: All claims expressed in this article are solely those of the authors and do not necessarily represent those of their affiliated organizations, or those of the publisher, the editors and the reviewers. Any product that may be evaluated in this article, or claim that may be made by its manufacturer, is not guaranteed or endorsed by the publisher.

Copyright (C) 2022 Wang and Chu. This is an open-access article distributed under the terms of the Creative Commons Attribution License (CC BY). The use, distribution or reproduction in other forums is permitted, provided the original author(s) and the copyright owner(s) are credited and that the original publication in this journal is cited, in accordance with accepted academic practice. No use, distribution or reproduction is permitted which does not comply with these terms. 